Click www.researchjournal.co.in/online/subdetail.html to purchase.

INTERNATIONAL JOURNAL OF PLANT PROTECTION

VOLUME 12 | ISSUE 1 | APRIL, 2019 | 84-86

- ISSN-0974-2670 | Visit us : www.researchjournal.co.in

\title{
Varietial and germplasm screening of Trigonella-foenum graecum L. against powdery mildew under field conditions in South Gujarat
}

\author{
A.U. Gojiya* and J.R. Pandya
}

Department of Plant Pathology, N.M. College of Agriculture, Navsari Agricultural University, Navsari (Gujarat) India

\section{ARITCLE INFO}

Received : 19.01 .2019

Accepted : 30.03 .2019

\section{KEY WORDS :}

Trigonella-foenum graecum L., Varieties, Germplasms, Powdery mildew, Screening

*Corresponding author:

Email : amit.gojiya144@gmail.com

\begin{abstract}
Two variety and thirteen germplasms of fenugreek (Trigonella-foenum graecum L.) were screened against powdery mildew under field condition. One germplasm FGK-94 was found resistant reaction to powdery mildew. While, three gremplasms FGK-97, FGK-98 and FGK-103 found to be moderately resistance. FGK-95, FGK-96, FGK-99, FGK-100, FGK-101 and FGK- 102 showed moderately susceptible reaction. Two variety Hissar sonali, RMT-361 and one germplasm FGK-104 showed susceptible reaction.
\end{abstract}

How to view point the article : Gojiya, A.U. and Pandya, J.R. (2019). Varietial and germplasm screening of Trigonella-foenum graecum L. against powdery mildew under field conditions in South Gujarat. Internat. J. Plant Protec., 12(1) : 84-86, DOI : 10.15740/HAS/IJPP/12.1/84-86, Copyright@ 2019: Hind Agri-Horticultural Society. 